POLLACK PERIODICA

An International Journal for Engineering and Information Sciences

DOI: $10.1556 / 606.2017 .12 .1 .13$

Vol. 12, No. 1, pp. 159-170 (2017)

www.akademiai.com

\title{
SPATIAL LAYOUT OF THE FUNCTIONS IN KULLA
}

\author{
${ }^{1}$ Mimoza SYLEJMANI, ${ }^{2}$ Gabriella MEDVEGY, ${ }^{3}$ Lulzim BEQIRI \\ ${ }^{1,3}$ Department of Architecture, Higher Education Institution, Kosovo \\ e-mail: ${ }^{1}$ mimoza.sylejmani@ubt-uni.net, ${ }^{3}$ lbeqiri@ubt-uni.net \\ ${ }^{2}$ Department of Architecture, Faculty of Engineering and Information Technology \\ University of Pécs, e-mail; ${ }^{2}$ medvegygabriella@mik.pte.hu
}

Received 27 December 2015; accepted 21 September 2016

\begin{abstract}
The paper deals with the analysis of the fortified dwellings - Kulla, which were constructed in Kosovo since XVIII-XIX century. As a case study, one took the Kulla, which were constructed in the Plain of Dukagjin. These types of dwellings were not constructed solely in Kosovo, but also in other countries of the region, that is: Northern Albania, Macedonia, and Montenegro. In Kosovo, the major parts of these buildings were constructed in the Plain of Dukagjin. Usually these buildings were constructed in two and three floors.

Characteristic feature of these buildings is the division of functions in vertical direction.

The research is based on the literature, analysis of the buildings, the research that was done up to now, including the interviewing of the persons-owners of the Kullas.

The aim was to get an understanding on the purpose of constructing the Kulla in vertical manner.

Kulla was analyzed in functional, architectural, constructive and condition aspect, which it offers to its inhabitants. There are a lot of factors that influenced on the construction of these buildings, one of them being the climate. Kosovo is characterized by a harsh climate during cold season of the year, which influenced on the relatively low height of the floors. Another feature is limited lighting in the ground floor, which increases steadily going further up to the last floor, as well as through the embrasures used for fire arms.
\end{abstract}

Keywords: Function, Architecture, Materials, Usability

\section{Introduction}

Kulla the fortified dwellings represent buildings that date from XVIII-XIX century. The major part of them was constructed in the Plain of Dukagjin. Many scholars have 
written regarding the Kulla as fortified dwellings, to name few of them: Flamur Doli, Fejaz Dranqolli, Njazi Haliti, Emin Riza, etc.

These buildings were constructed using circumstantial material: stones, wood, sand, soil, as well as processed materials like: lime, roof tiles, adobe. The walls of the towers are built from stone, while the structure from timber [1]. In Macedonia also encountered two storey houses built mainly of stone [2].

There are many factors that influenced on the construction of Kulla, among them the climate. Kosovo is characterized by a harsh climate during cold season of the year, which influenced on the relatively low height of the floors [3, pp. 211-213]. These buildings were constructed by the Albanian masters, especially those from Dibra. The masters from Dibra would construct the Kulla up to and including the roof, whereas other decorative works would be done by other masters. The Kulla in the cities were exclusively built by the masters from Dibra. These buildings did not have any religious character; they were built equally by Muslims and Catholics [4, pp. 90].

As a result of the greater congestion of the population, these buildings were initially built in villages, only to continue their construction in the towns and they were not built only by the wealthy, but also by the common villagers, however, the latter would be more modest in appearance and regarding the construction and aesthetic aspect. The characteristic feature of these buildings was division of functions in the floors.

Initially, the fortified dwellings - Kulla, were constructed from stone and wood, but with the advancement of technology, they started to be constructed entirely by stone. With the emergence of the reinforced concrete, one witnessed the end of construction of the most characteristic buildings in Kosovo.

The characteristic feature of these building is their multifunctional application, in addition to these buildings being used for living; they were also used as shelter during the times of danger, to shelter the livestock, as well as for various gatherings during the National Movement of Albanians. The Kulla were surrounded with a fence and the life within the complex of Kulla would easily take place within the building without a need to go outside its complex.

The heights in terms of floors would depend on the financial situation of the person who would commission the construction of the building, or as a result of the number of the members of the family. The Kulla were constructed with walls that were 70-90 cm thick, their width would decrease going upwards from floor to floor, in a gradual manner and in the inner side [4, pp. 130]. Unfortunately today these cultural heritage buildings are at risk of extinction [5]. The major part of Kulla is not used any more, whereas some of them have their use shifted by transforming them from individual housing building, into inns.

Swedish organization, Cultural Heritage without Borders-CHwB sees potential for development of tourism in Plane of Dukagjini, where we encounter a large number of such facilities [6]. 


\section{Typology of Kulla}

Initially, the Kulla had a simple cubical shape; however with passing of the time they were attached an exterior lobby, which rendered the Kulla more aesthetic, as a result of the light shades which results from these lobbies.

There are two types of Kulla:

- Kulla with wooden top floor gallery, (Fig. 1); and

- Kulla with stone top floor gallery, (Fig. 2).

Kullas with wooden gallery were built in earlier stages, however, with the advancement of the technology, given that the wood was not a material that resisted wear and tear with passing of time, one started to construct Kulla with stone gallery. This structure is found in the top floor of Kulla and it has little windows that finish in the form of semi arch.

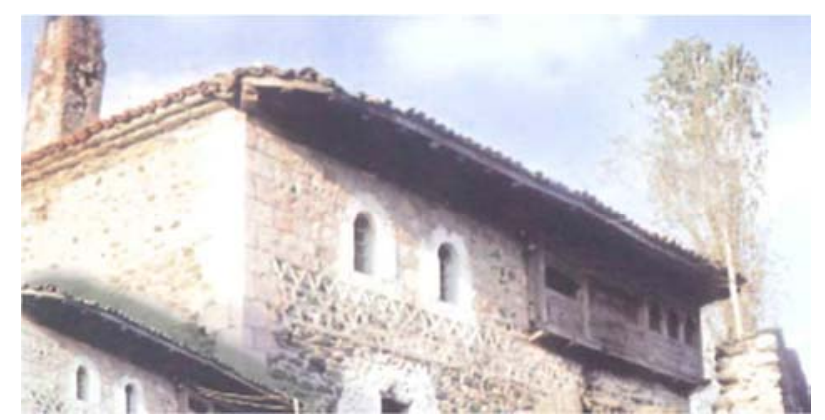

Fig. 1. Kulla with wooden gallery, source: with permission of Flamur Doli, [7, pp. 29, Fig. 2]

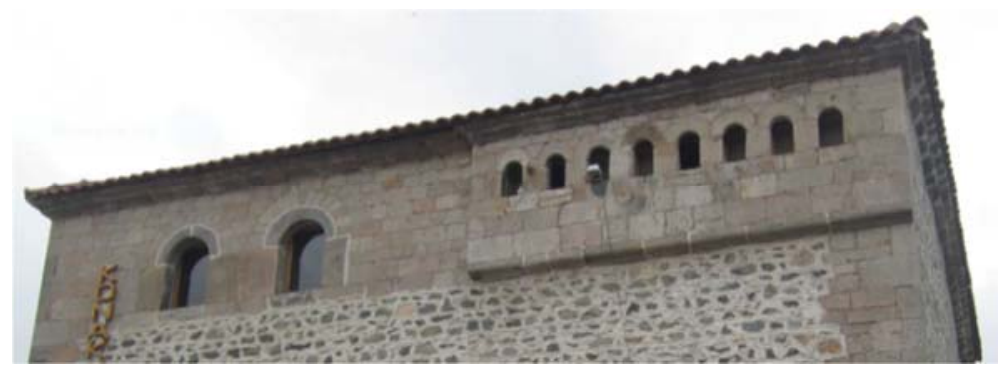

Fig. 2. Kulla with stone top floor gallery, source: Author's photography in September 2015

This type of gallery was found in the center part of the front wall of Kulla, in all the length of front wall, or in the other shapes as presented in the Fig. 3, which enabled the presence of aesthetic forms facing the road, as well as towards the entrance to the complex of Kulla.

These are the types of Kulla based on the expanse of gallery. 


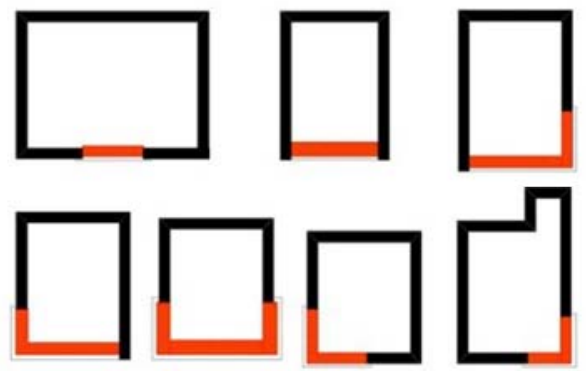

Fig. 3. Typology of Kulla in the Plain of Dukagjin, depending on the presence of gallery, source: redrawn by the Author on the basis of [8, pp. 192, Fig. 58]

\section{Analysis of Kulla}

The word Kulla derives from Arabic and it means castle, a residential building with expressive defensive features, commonly built in three floors, built with a stone masonry with minimum lighting surface and with embrasures for fire arms [9, pp. 76].

The major parts of Kulla in Kosovo country were constructed in the Plain of Dukagjin, Junik represents one of the places where one finds a relatively large number of fortified dwellings - Kulla. During the years, Kulla underwent significant changes. They were damaged to a large extent during the time of Turkish Rule; some of them were burnt down, whereas some of them underwent changes like closing of embrasures for fire arms, extension of the openings, tearing down of karollhane, etc. The main aim was to weaken the Albanian resistance. Many of the Kulla that were burnt down during the Turkish Rule, were reconstructed afterwards, however they were burnt down again this time by the occupying Serbian forces, in 1998-1999.

One should also not forget that some of the changes in the Kulla were done by the owners of the Kulla, (Fig. 4), by attempting to adapt them for the modern way of living [4, pp. 111].

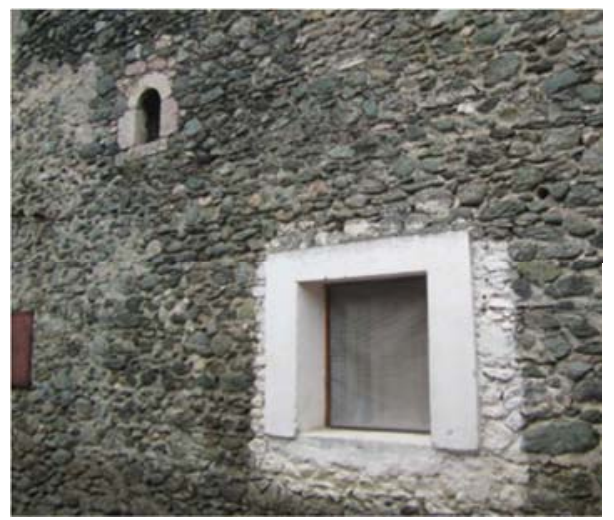

Fig. 4. Changes into aperture 
The men's room represents the main area within Kulla, which is features constantly and which never changed. This room was only added addition space be it in horizontal way, also in vertical way, as it is seen in the special development-evolution diagram of the Kulla of the type of Plain of Dukagjin [9, pp. 186] (Fig. 5).

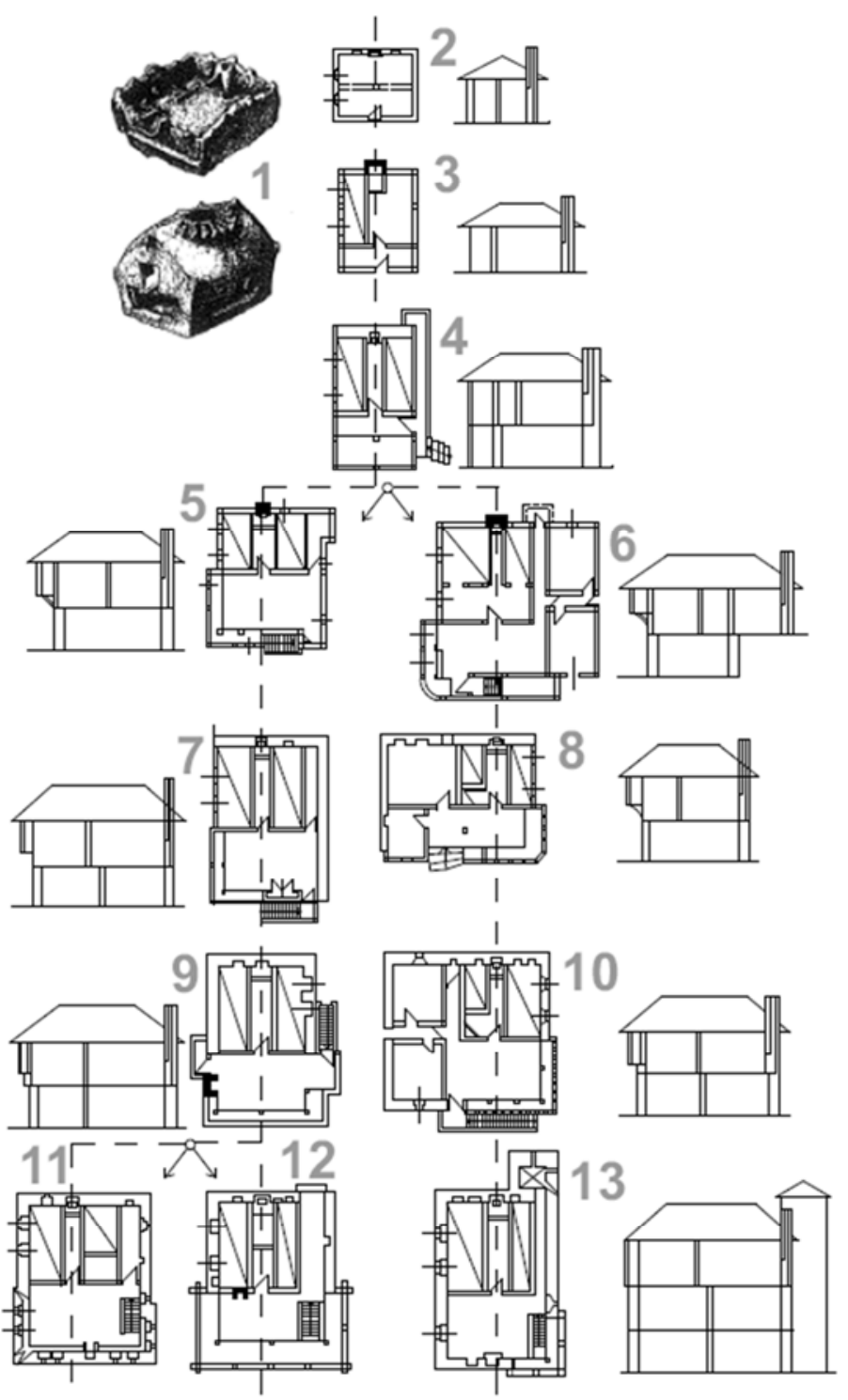

Fig. 5. Diagram on spatial development-evolution of the Kulla of the type of plain of Dukagjin, source: with the permission of Flamur Doli [9, pp. 186, Fig. 44] 


\subsection{KullaA of Jahe Imeri}

Kulla was constructed in XIX century; it is located in the heart of town of Junik, near the mosque. It belongs to the Kulla with stone gallery.

In Fig. 6 exterior façade of Kulla of Jahë Imeri is shown.

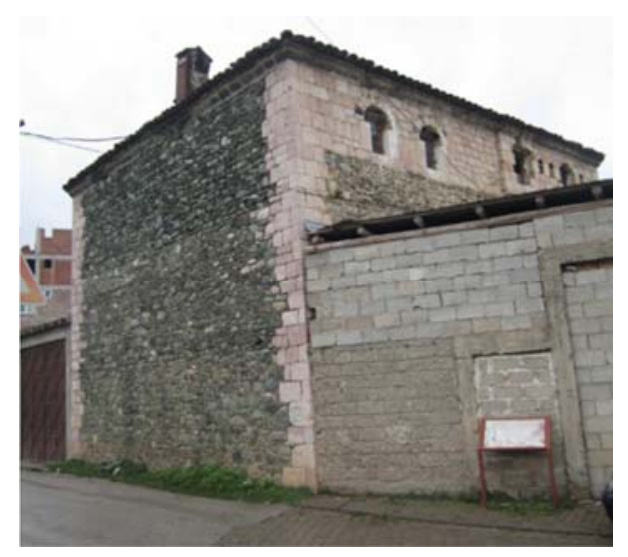

Fig. 6. Kulla of Jahe Imeri, Junik, source: Author's photography in September 2015

The second floor has three rooms, one with chimney and two bed rooms.

This part of the building was mainly used by the women and it was called 'fire house' (Fig. 7), this area served for daily stay, however in certain cases it was also used for children to sleep in it.

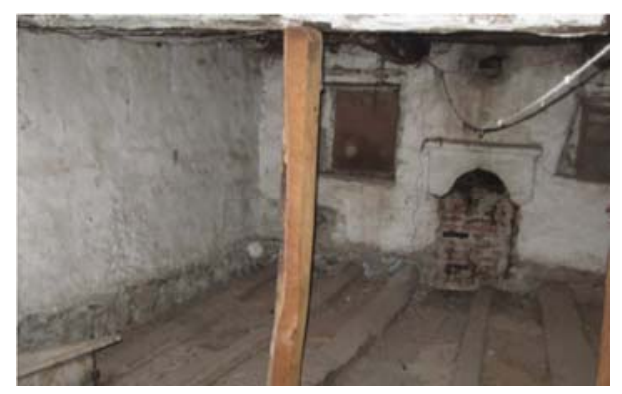

Fig. 7. The present condition of the House of Fire, Kulla of Jahe Imeri, Junik, source: Author's photography in September 2015

In the third floor there is the men's room (Fig. 8), the lobby and the bathroom (Fig. 9). Every time in the direction of the road is an opening, which provides better view towards entry into the tower complex (Fig. 10).

Nowadays the Kulla is in deplorable condition, the owners lack the means to renovate it, and there is a lack of funds to renovate it. 


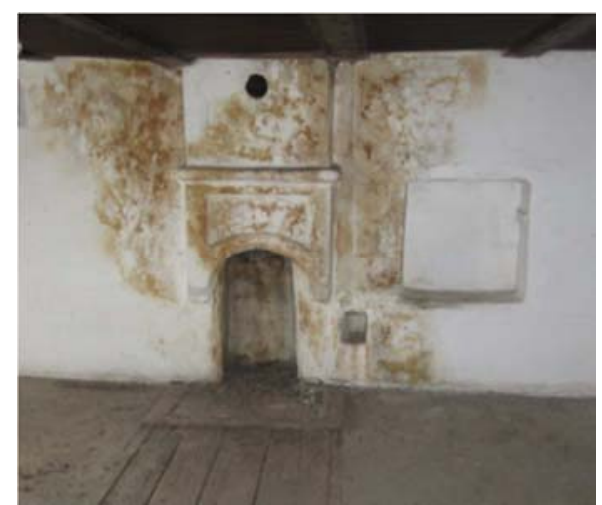

Fig. 8. Men's room

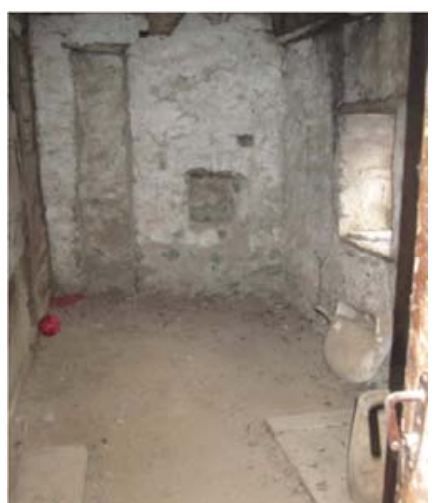

Fig. 9. Bathroom

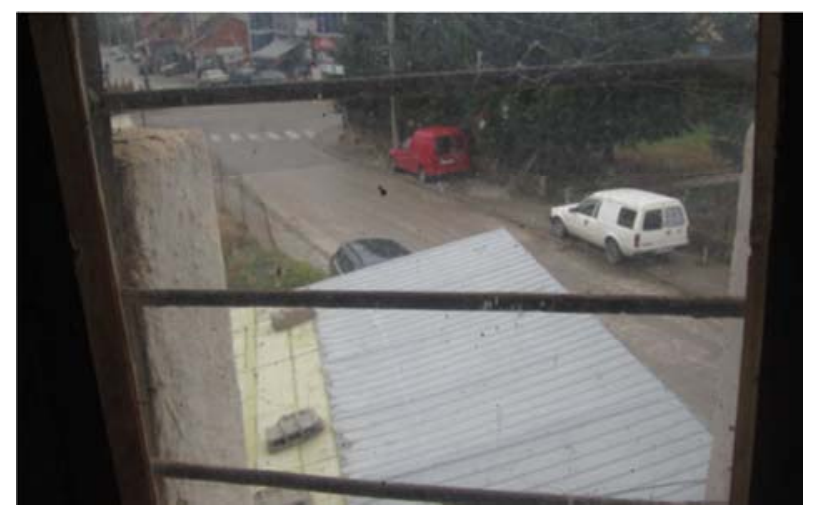

Fig. 10. The window, view towards the street

In Fig. 11 dishes can be observed, which are encountered, at the time the building was visited, in September 2015.

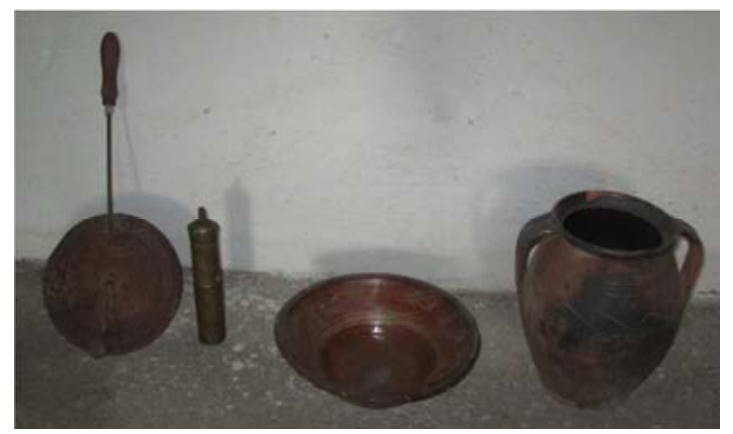

Fig. 11. Dishes

Source: Fig. 8, 9, 10, 11: Author's photography in September 2015 


\subsection{Kulla of Rame Zyberi}

Kulla of Rame Zyberi (Fig. 12, Fig. 13) was constructed in 1860 and it was inherited by three generations of the family. This Kulla belongs to the group of Kulla with stone gallery. The renovation of this Kulla started in 2004 and it was finished in 2007. The Kulla is renovated by its heirs, with the goal of preserving the tradition. Initially, there were 25 members of family that lived in it, whereas today it is used as an inn. The ground floor was initially used as a stable for sheltering the livestock; today it is used as a restaurant (Fig. 14), whereas the floors are used as guest rooms for sleeping (Fig. 15), also as living room during the day (Fig. 16) and (Fig. 17).

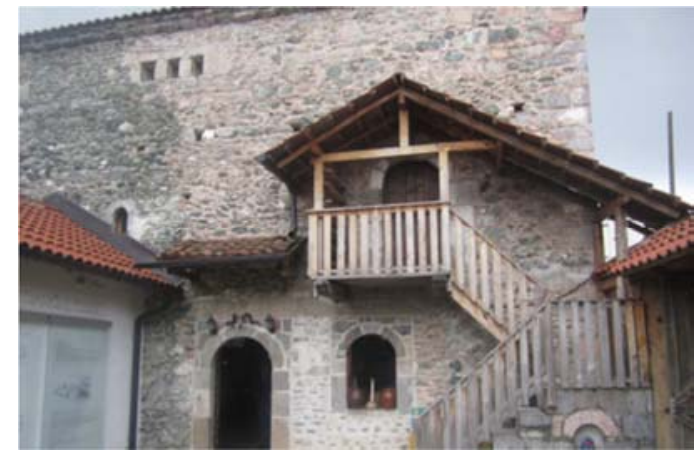

Fig. 12. Kulla of Rame Zyberi

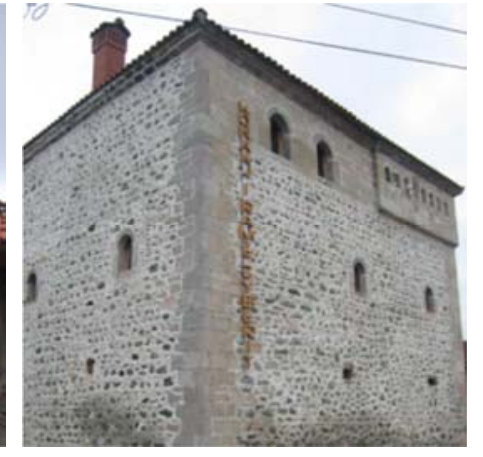

Fig. 13. Entrance to Restaurant

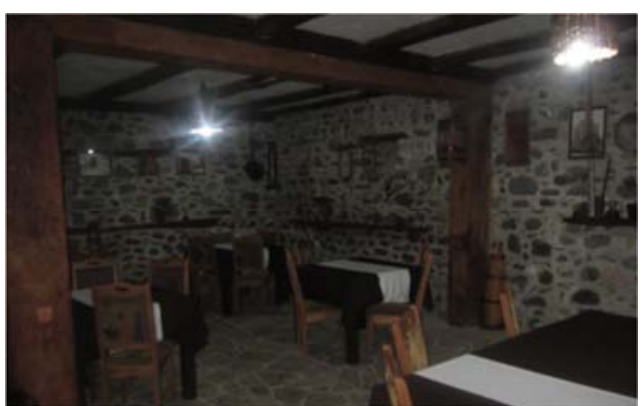

Fig. 14. Former stable that is nowadays is used as restaurant

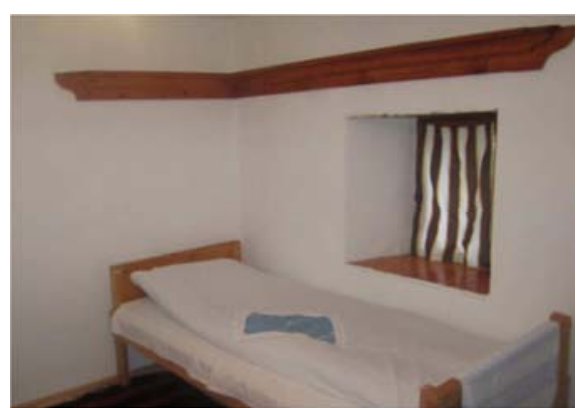

Fig. 15. Sleeping area

During the planning of the individual dwellings, one always tried to clearly define the living rooms from those used for sleeping, and they oriented the living rooms towards the calmer part of the yard where the building was constructed. The orientation of the main areas it was done facing the yard, thus enabling greater degree of intimacy (Fig. 18). 


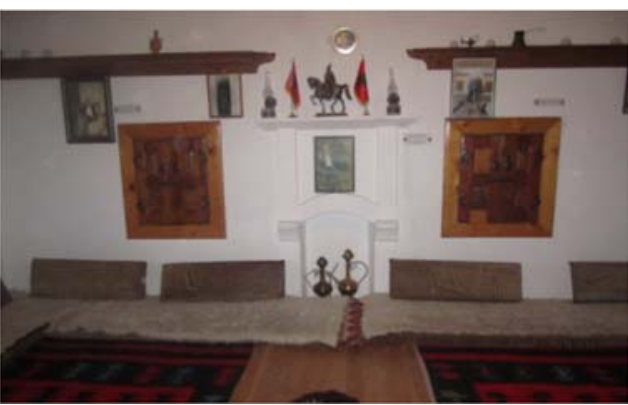

Fig. 16. Men's room

Source: Fig. 12, 13, 14, 15, 16, 17: Author's photography in September 2015
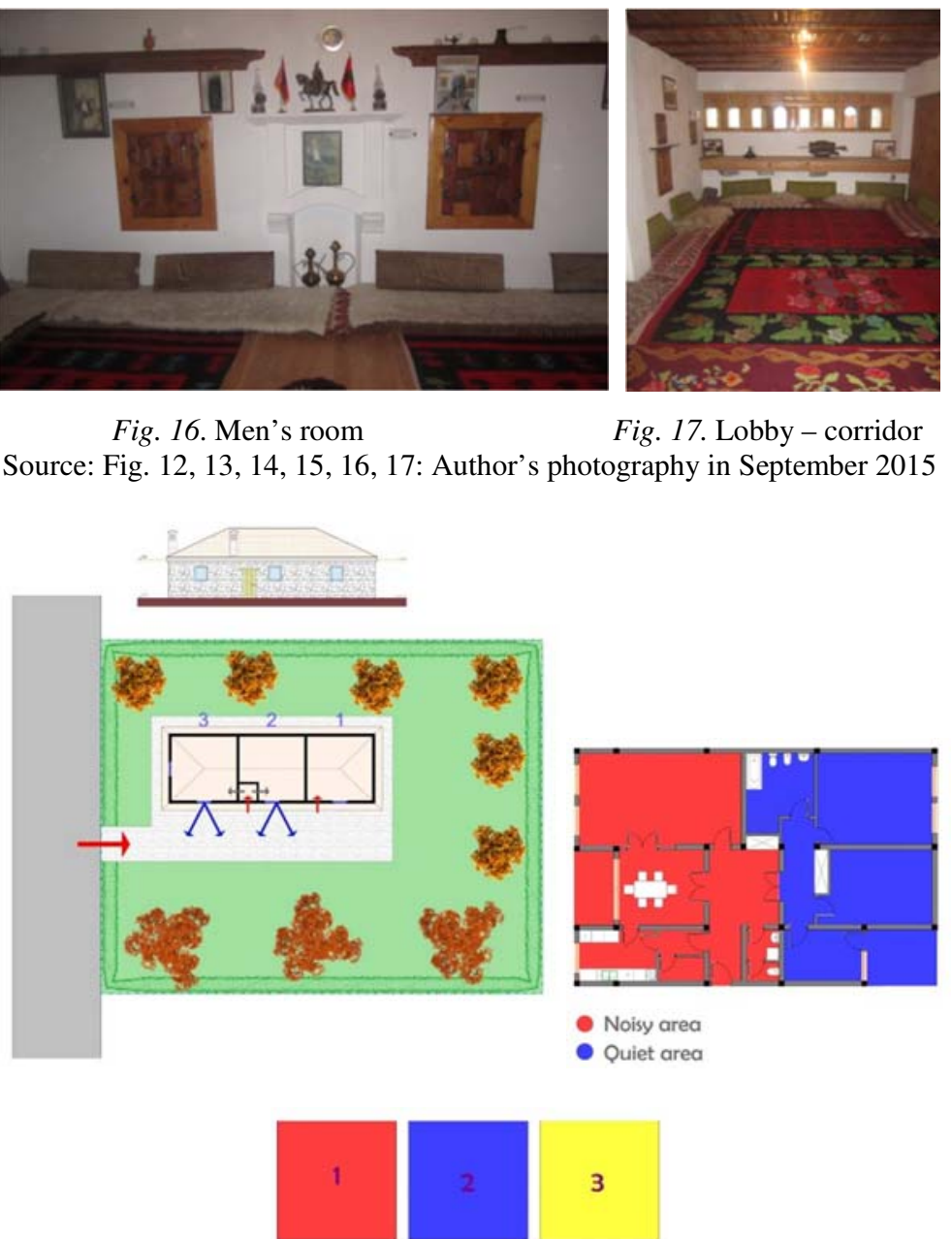

Fig. 17. Lobby - corridor

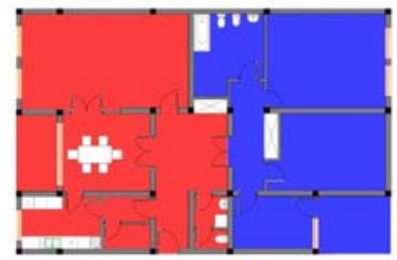

- Noisy area

- Quiet area

Fig. 18. Concept of individual residential building - ground floor 1. Living area; 2. Sleeping area; 3 . Economic activity area, Source: Author's drawing in September 2015

At the residential building - Kulla, the division of the functions was done in floors (Fig. 19) and the orientation of main areas was done towards the street and the entrance to the complex of Kulla.

1. Stable or the economic activity area served to shelter the livestock. The entry to this area was through a low door, which usually was covered with a semi arch

2. The Fire House or the 'room of the women' was the area that served for preparation of the food, and in certain cases for children to sleep in. The height ranged from $210-220 \mathrm{~cm}$. 
3. Men's Room was the main area within Kulla, which was located in the top floor of the Kulla and it had two functions. During the day it was used to stay in it, whereas during the night it was used for sleeping by the guests or the unmarried men. There are cases when it top floor there was a room for the old man of the house. This area was used only by men and it had a separate access way through wooden stairs.

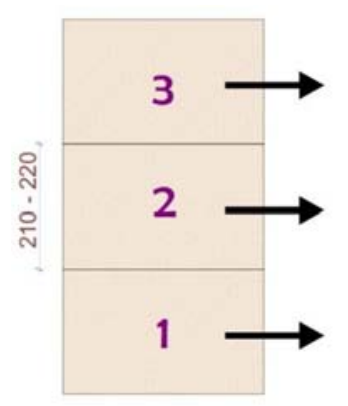

Fig. 19. Individual residential building concept - Kulla - P+2, source: Author's drawing in September 2015

Entire Kulla was surrounded with embrasures, which were used for fire arms in case of danger (Fig. 20).

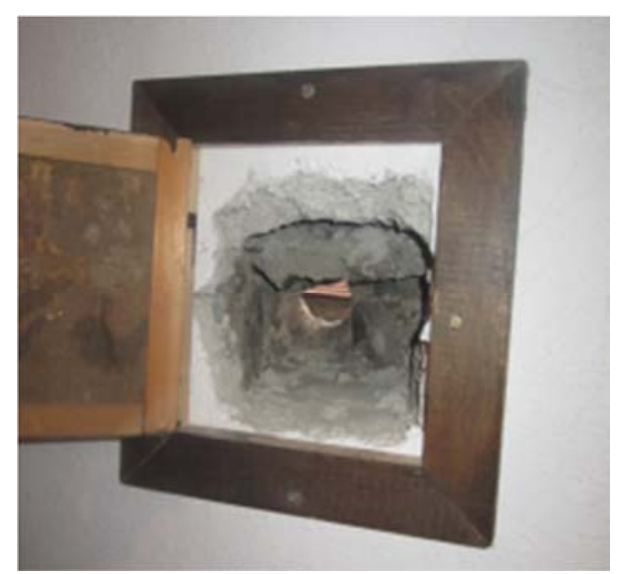

Fig. 20. Embrasure for fire arms source: Author's photography in September 2015

During the construction of the Kulla, the extension of it was planned, which would enable connecting the Kulla through an annex building, in case the member of the family increased (Fig. 21, Fig. 22), or one would construct new Kulla, thus forming an ensemble of Kullas (Fig. 23). 


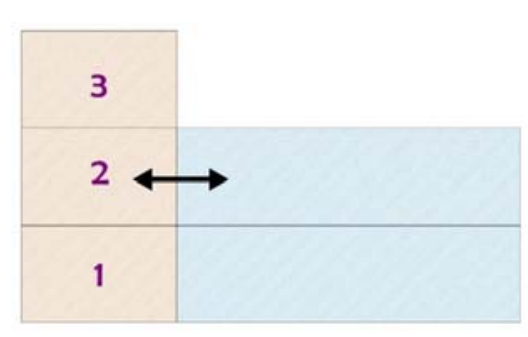

Fig. 21. Extension of the Kulla in case of increase of members of family, source: Author's drawing in September 2015

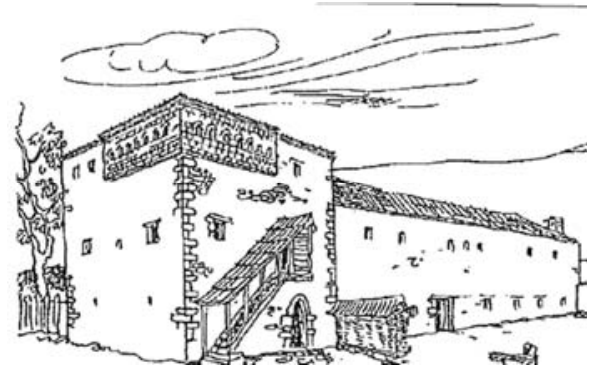

Fig. 22. Istog. Kulla in Saradran of Istog source: with the permission of Flamur Doli [8, pp. 222, Fig. 136]

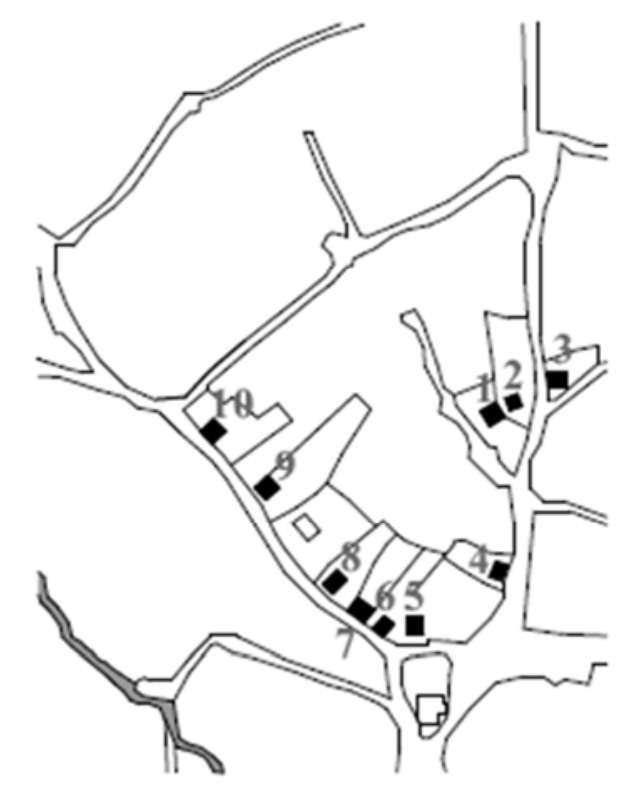

Fig 23. Development of the urban residential complex in the neighbourhood of Tergovishte of Hoxhaj in Junik, source: with the permission of Flamur Doli [8, pp. 196, Fig. 69]

\section{Conclusion}

Kulla represents one of the most characteristic buildings constructed in our country, be it regarding the construction technique, also regarding the architecture.

The characteristic feature of these buildings is the division of the functions in vertical direction of the building. Based on the analysis of the residential function of the building, especially the aspect of special function, also based on the references to the current literature on Kulla and the individual research that was done on these buildings, 
always with the aim of striving to get an answer on the question why these towers were built in floors, one derives the conclusion that the reason these buildings were constructed vertically was not with the aim of saving the land or any other reason, however the reason was merely due to security concerns, given that every family took care of personal security in the absence of an organized security system in various historical periods, especially during the time these buildings were constructed. This concept is related to the construction of castles which in terms of security aspect provided shelter to a larger community (location), however when one deals with Kulla they are smaller in terms of size, which influenced directly the size of Kulla. The height of the building offered better view towards the street and the entrance to the Kulla complex, thus increasing the sense of security for the members of the family.

\section{References}

[1] Hoxha V. Y. Architectural characteristics of urban dwellings in Kosovo, in Proceedings of $4^{\text {th }}$ UBT- International Conference on Architecture and Spatial Planning, Durrës, 30 November 2015, pp. 69-78, http://conferences.ubt-uni.net/digital-proceedings/books/ Architecture, (last visited 29 September 2015).

[2] Ivkovska V. Re-inventing vernacular settlements for tourists; Can the new Macedonian village represent true vernacular traditions? Journal of the International Society for the Study of Vernacular Settlements, Vol. 3, No. 2, 2014, pp. 17-34, http://isvs.lsai.org/ pdf/ISVS_3-2/Vol3Issue22\%20Velika\%20Final.pdf, (last visited 29 September 2015).

[3] Riza E. City and Albanian dwelling of the late middle ages, (in Albanian), Academy of Science of Albanian, Tiranë, Albania, 1991.

[4] Drançolli F. Albanian Kulla, (in Albanian), Grafika Reznioi, Prishtinë, 2001.

[5] Rexhepi A. Mahdavi A. Empirical and computational study of the thermel performance of a traditional housing type in Kosovo, in Third German-Austrian IBPSA Conference, Viena University of Technology, Austria, http://www.ibpsa.org/?page_id=145, pp.86-91 (last visited 1 September 2015).

[6] CHwB-Cultural Heritage without borders, See you in Dukagjin (2010-2013) and Wellcome to Dukagjin (2011-2013), http://chwb.org/kosovo/resources/latest-publications/, (last visited 1 September 2015).

[7] Doli F. Traditional popular architecture of Kosovo, (in Albanian) Kosovo, 2001.

[8] Doli F. Vernacular Architecture of Kosovo, (in Albanian) Prishtinë, 2009,

[9] Haliti R. N. Dwelling citizen Kosovarien in XVIII-XIX century, (in Albanian) Academy of Science and Arts of Kosovo, Prishtinë, 2006. 